\title{
Pendidikan P3K Luka dan Perdarahan pada Patroli Keamanan Sekolah Satlantas Polres Tegal
}

\author{
Woro Hapsari ${ }^{1}$, Arriani Indrastuti ${ }^{2}$ \\ STIKES Bhamada Slawi, Jalan Cut Nyak Dien No.16, Kalisapu, Slawi, Kalisapu, Kec. Slawi, \\ Tegal, Jawa Tengah 52416 \\ Email: hworo@ymail.com
}

\begin{abstract}
ABSTRAK
Pendahuluan: Patroli Keamanan Sekolah adalah kegiatan ekstra kurikuler disekolah dalam rangka menjaga lingkungan keamanan dan ketertiban dilingkungan sekolah, seiring dengan perkembangan Patroli Keamanan Sekolah juga diharapkan dapat memberikan pertolongan pertama ketika terjadi kecelakaan disekolah antara lain apabila terjadi luka dan perdarahan yang disebabkan oleh kecelakaan yang tidak terduga dilingkungan sekolah Ada beberapa jenis luka yang dapat terjadi dilingkungan sekolah antara lain : luka lecet, luka parut, terpotong, teriris dan luka gigitan. diharapkan dengan penanganan dini dapat meminimalisir komplikasi lebih lanjut anggota Patroli Keamanan Sekolah dapat melakukan penanganan tersebut, Permasalahan: yang ada pengetahuan dalam penanganan pertama pada luka dan perdarahan masih kurang dengan adanya pendidikan P3K luka dan perdarahan akan terjadi peningkatkan pengetahuan tentang penanganan pertama pada luka dan perdarahan dengan dibekali pengetahuan tentang jenis luka dan perdarahan, cara penanganan luka dan perdarahan dan cara membalut luka dan menghentikan perdarahan. Metode: yang digunakan adalah Focus Group Discussion (FGD) dengan membagi kelompok besar menjadi 2 kelompok kecil Hasil: terjadi peningkatan pengetahuan $85 \%$ dengan diberikan pertanyaan tentang pengertian luka dan perdarahan serta mampu mengulang kembali tata cara penatalaksanaan luka dan perdarahan. dengan terjadinya peningkatan pengetahuan diharapkan anggota PKS dapat menangani luka dan perdarahan lebih dini dan meminimalisir komplikasi lebih lanjut akibat perdarahan.
\end{abstract}

Kata Kunci : Patroli keamanan Sekolah; Satlantas Polres Tegal; P3K luka dan perdarahan

\begin{abstract}
Introduction: School Safety Patrol is an extra-curricular activity at school in the context of maintaining an environment of security and order in the school environment, along with the development of the School Safety Patrol is also expected to provide first aid when an accident occurs at schools such as if there are injuries and bleeding caused by unexpected accidents in the environment school There are several types of injuries that can occur in a school environment including abrasions, scars, cuts, cuts and bite wounds. It is hoped that early treatment can minimize further complications. School Safety Patrol members can do the handling, The problem: that there is knowledge in the first treatment of wounds and bleeding is still lacking with the education of $\mathrm{P} 3 \mathrm{~K}$ injuries and bleeding will increase knowledge about the first treatment of wounds and bleeding with knowledge of the types of wounds and bleeding, how to treat wounds and to bleed and how to bandage wounds and stop bleeding. The method: used is a Focus Group Discussion (FGD) by dividing large groups into two small groups. The result: is an $85 \%$ increase in knowledge with questions about the understanding of wounds and bleeding and being able to repeat procedures for wound and bleeding management. With the increase in knowledge, it is hoped that PKS members can manage injuries and bleeding early and minimize further complications due to bleeding.
\end{abstract}

Keywords: School security patrol; Satlantas Polres Tegal; First Aid Injury and bleeding 


\section{PENDAHULUAN}

Patroli Keamanan Sekolah atau yang disingkat PKS adalah salah satu jenis kegiatan ekstra kurikuler yang ditemui disekolah, PKS awal dibentuk pada tanggal 5 Mei 1975 dengan nama polisi keamanan sekolah untuk memperluas ruang lingkupnya pada tanggal 5 Juni 1975 oleh Bapak Letkol Anton Sudjarwo nama polisi keamanan sekolah diganti menjadi patroli keamanan sekolah. Menurut petunjuk pelaksanaan No Pol : Juklak/2/VII/84/Lantas tentang pembentukan patroli keamanan sekolah dari kepala dinas lalu lintas POLRI tertanggal 28 Desember 1984 patroli keamanan sekolah adalah suatu organisasi yang merupakan wadah dalam partisipasi para pelajar yang berminat dalam bidang pengetahuan lalu lintas, khususnya dalam mengatur penyeberangan pada jalan umum disekitar sekolahnya masing-masing. Keberadaan patroli keamanan sekolah diperkuat oleh adanya petunjuk pelaksanaan Kepala Kepolisian Negara Republik Indonesia no pol : Juklak/05/V/2003 dikeluarkan diJakarta Tanggal 29 Mei 2003 yang disyahkan oleh Badan pembinaan Keamanan Komjen Pol Drs Adang Daradjatun, dalam juklak tersebut menjelaskan bahwa tentang Patroli Keamanan Sekolah adalah sebuah wadah dari partisipasi pelajar dibidang lalu lintas yang mempunyai peranan dalam menanamkan kebiasaan bertingkah laku yang benar dijalan. Dalam pembinaan kemampuan PKS salah satu kemampuan dasar teori yang wajib didapatkan adalah pengetahuan dasar tentang $\mathrm{P} 3 \mathrm{~K}$.

Pertolongan pertama pada kecelakaan atau disingkat P3K adalah suatu perawatan awal pada cedera sasaran kunci dari pertolongan pertama adalah menyelamatkan kehidupan manusia, mencegah bahaya lebih lanjut dan pemulihan lebih lanjut (Soedirman, 2013) Dalam melakukan pertolongan prinsip pertolongan ada tiga macam. Pertama siap diri di dukung dengan ada kemauan, ada ilmu dan memiliki ketenangan. Kedua, Safety yang meliputi lingkungan, penolong dan korban. Ketiga adanya respon yang meliputi cek kesadaran dan keadaan korban beberapa kejadian yang sering terjadi di sekolah adalah pingsan, sesak nafas, mimisan dan luka serta perdarahan dari tiga kejadian yang sering terjadi diantaranya pada siswa adalah pingsan, mimisan kejadian yang tidak terduga adaalah luka ada beberapa jenis luka yang biasa terjadi dalam kecelakaan dilingkungan sekolah yaitu, luka lecet (vulmus excorias), luka parut (laserasi), terpotong atau teriris dan luka gigitanya yang disebabkan karena jatuh pada saat olah raga atau kegiatan disekolah ( Hardisman, 2014) 
Proses penanganan luka ada tahapan yang bisa dilakukan seperti membersihkan luka, kemudian dikeringkan dan tutup bagian luka jika perlu. Penanganan seperti inilah yang bisa mengatasi dan meminimalisir dampak lebih parah seperti perdarahan yang hebat. Penanganan dasar seperti ini bisa dilakukan pada semua kalangan tidak terkecuali yang ada dilingkungan sekolah terutama anggota Patroli keamanan Sekolah.

Satlantas Polres Tegal membina Patroli keamanan sekolah SMU SMK di wilayah Kabupaten Tegal dengan mengadakan kegiatan kegiatan rutin seperti Latsa dan latgab dalam kegiatan tersebut ada latihan baris berbaris, kedisiplinan, kekompakan, Gerakangerakan pengaturan lalu lintas, yang biasanya di terapkan di lingkungan sekolah masingmasing.

Bentuk partisipasi siswa PKS terhadap sekolahnya disamping kegiatan yang rutin dilakukan PKS juga perlu mendapatkan pembekalan tentang P3K luka dan perdarahan karena masalah ini dapat terjadi kapan saja dan dimana saja. Permasalahan mitra adalah pengetahuan dan ketrampilan tentang pertolongan pertama pada luka dan perdarahan masih kurang dengan adanya pendidikan P3K luka dan perdarahan maka akan terjadi peningkatan pengetahuan dan ketrampilan tentang penanganan luka dan perdarahan sehingga dapat meminimalisir komplikasi lebih lanjut seperti infeksi dan syok akibat perdarahan. Metode yang dugunakan dalam kegiatan ini adalah dengan Focus Group Discussion (FGD) dengan membagi kelompok besar dengan kelompok yang lebih kecil yang menjadi target dalam pengabdian kepada masyarakat ini adalah : Mengenali dan memahami jenis pembuluh darah pada manusia, mampu menilai keadaan luka dan penanganan perdarahan, mampu melakukan pertolongan pada luka dan perdarahan, Terjadi peningkatan pengetahuan tentang pertolongan pertama luka dan perdarahan pada kecelakaan yang kemungkinan terjadi diwilayah sekolah.

Luaran yang diharapkan dari kegiatan ini adalah anggota PKS Satlantas Polres Tegal akan terjadi Peningkatan pengetahuan pertolongan pertama luka dan perdarahan antara lain: memahami jenis pembuluh darah pada manusia, mengetahui jenis jenis luka, perdarahan dan peserta mampu melakukan melakukan balutan dan cara menghentikan perdarahan

\section{METODE PELAKSANAAN}

Pelaksanaan kegiatan pengabdian kepada masyarakat dilaksanakan selama 2 hari yaitu dengan pada hari Jumat dan Sabtu Tanggal 21- 22 Februari 2020 yang diawali penyampaian gagasan awal kegiatan adalah hasil diskusi dengan pembina Patroli Kemanan Sekolah Satlantas Polres Tegal dengan Dosen Prodi DIII Keperawatan berkaitan dengan 
kegiatan untuk meningkatkan pengetahuan tentang pertolongan pertama pada kecelakaan perdarahan dan luka setelah mensepakati jadwal kegiatan bersama tersebut maka membuat rencana kegiatan, Dalam kegiatan pengabdian masyarakat ini metode yang digunakan adalah Focus Group Discussion (FGD) dua kelompok masing masing kelompok akan diampu oleh satu penyaji dengan model Focus group Discussion memberikan materi tentang : Jenis pembuluh darah pada manusia, perdarahan menilai keadaan luka, penanganan luka perdarahan dan mendemonstrasikan perawatan luka dan mengentikan perdarahan pada salah satu anggota patroli keamanan sekolah. Alat yang dibutuhkan dalam pendidikan P3K luka dan perdarahan adalah kit P3K khusus untuk luka dan perdarahan antara lain : bak instrumen sedang, kassa steril, kassa gulung, plester/hipavik,cairan pencuci luka (Nacl 0,9\%), gunting, kain mitella, betadine atau obat untuk luka.

a. Jadwal Kegiatan

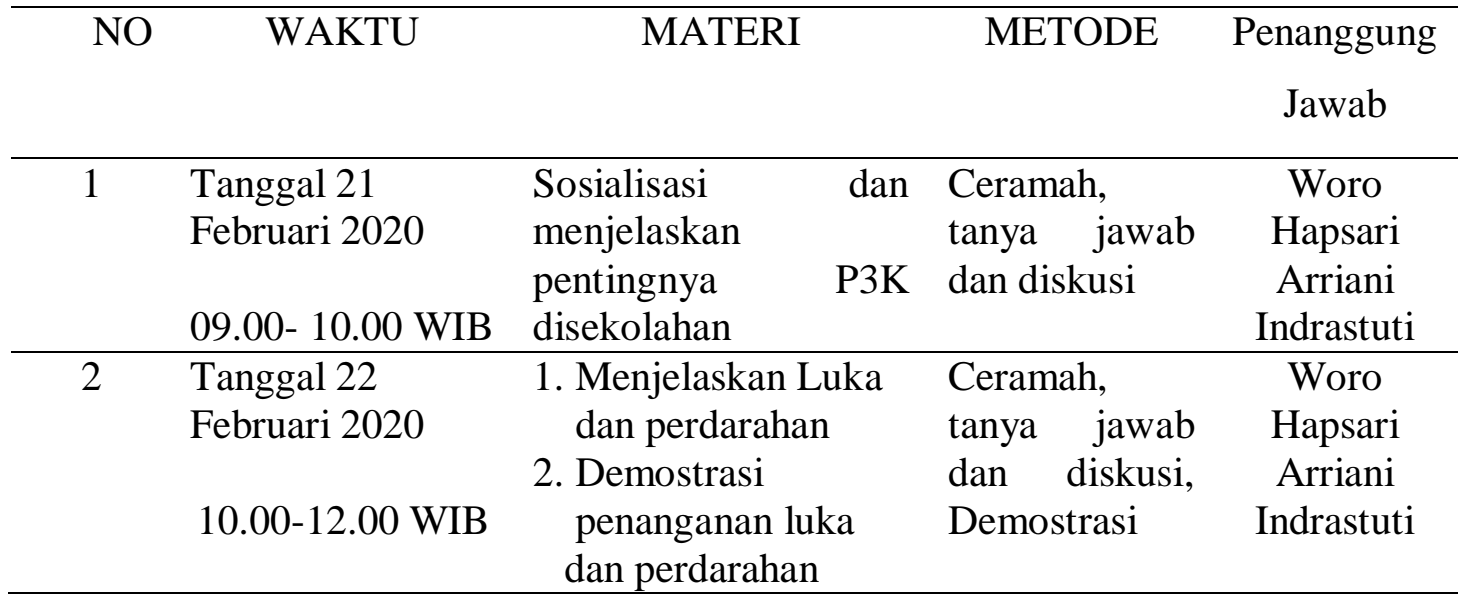

b. Kehadiran

Kegiatan ini dihadiri oleh penyaji Dosen Prodi DIII Keperawatan sejumlah 2 orang dan peserta Patroli Keamanan Sekolah sejumlah 145 peserta

\section{HASIL DAN PEMBAHASAN}

Hasil pelaksanaan kegiatan pengabdian kepada masyarakat secara garis besar dapat dijelaskan sebagai berikut kegiatan dilakukan selama Sekolah dengan hasil terjadi peningkatan pengetahuan tentang penanganan luka dan perdarahan yang mungkin terjadi di lingkungan sekolah, Kemampuan peserta dalam penguasaan materi dapat dinilai cukup baik $85 \%$, hasil dari tanya jawab dan kuis (test ) dengan pertanyaan antara lain : Jenis pembuluh darah pada manusia, jenis luka, tanda perdarahan, jenis alat yang dibutuhkan dalam penanganan luka dan perdarahan, keterbatasan hal ini dikarenakan penyampaian 
materi dan simulasi yang singkat dengan waktu yang terbatas maka dapat menyebabkan peserta kurang paham dengan materi yang diberikan karena tidak bisa satu persatu peserta mempraktekan penanganan luka dan perdarahan. Dari kehadiran peserta $100 \%$ hadir sesuai dengan rencana awal antusiasme peserta dapat dinilai baik terbukti dari respon aktif diskusi pada saat kegiatan, Dari penilaian komponen diatas dapat disimpulkan bahwa kegiatan dapat dinilai baik kegiatan pengabdian kepada masyarakat kerjasama Stikes Bhamada dan Patroli Keamanan Sekolah Satlantas Polres Tegal sehingga tahun berikutnya diharapkan ada kegiatan lanjutan untuk mendukung upaya peningkatan pemahaman dan ketrampilan masyarakat dalam menangani luka dan perdarahan dilingkungan sekolah.

Dari rangkaian kegiatan dapat dilihat dari foto kegiatan :

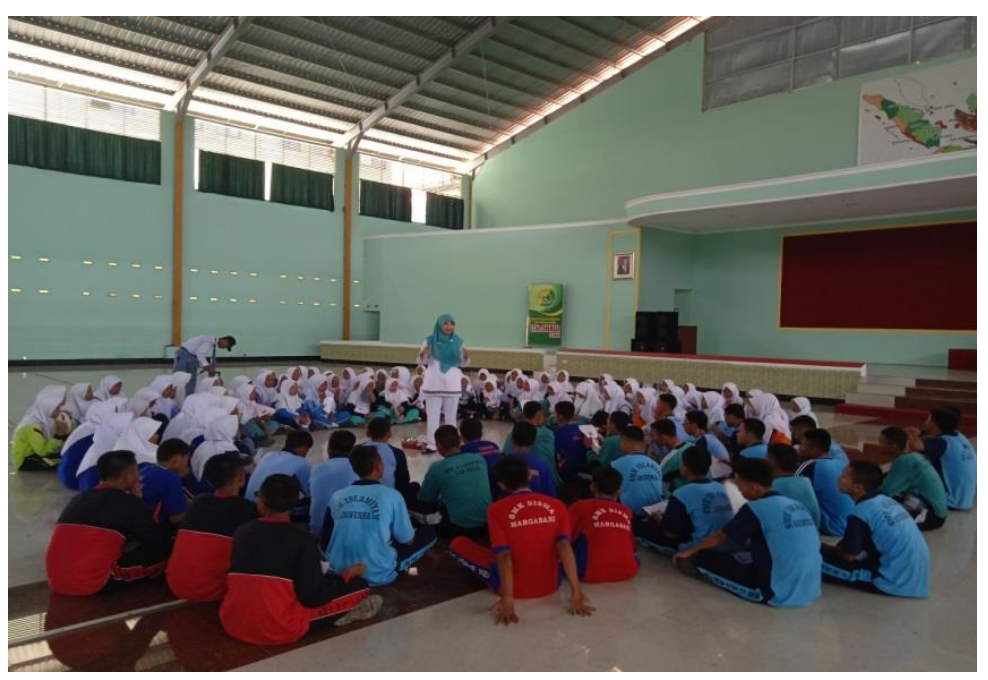

Gambar 1. Menjelaskan tentang Luka dan perdarahan serta jenis jenis luka dan pembuluh darah pada manusia

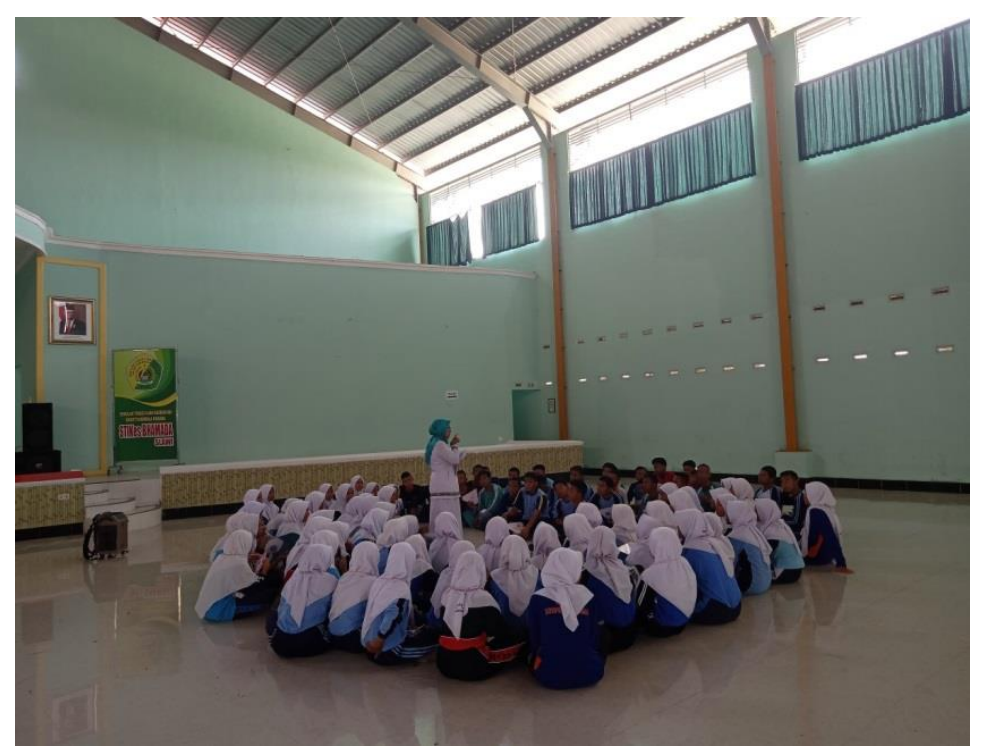

Gambar 2. Menjelaskan luka dan perdarahan 


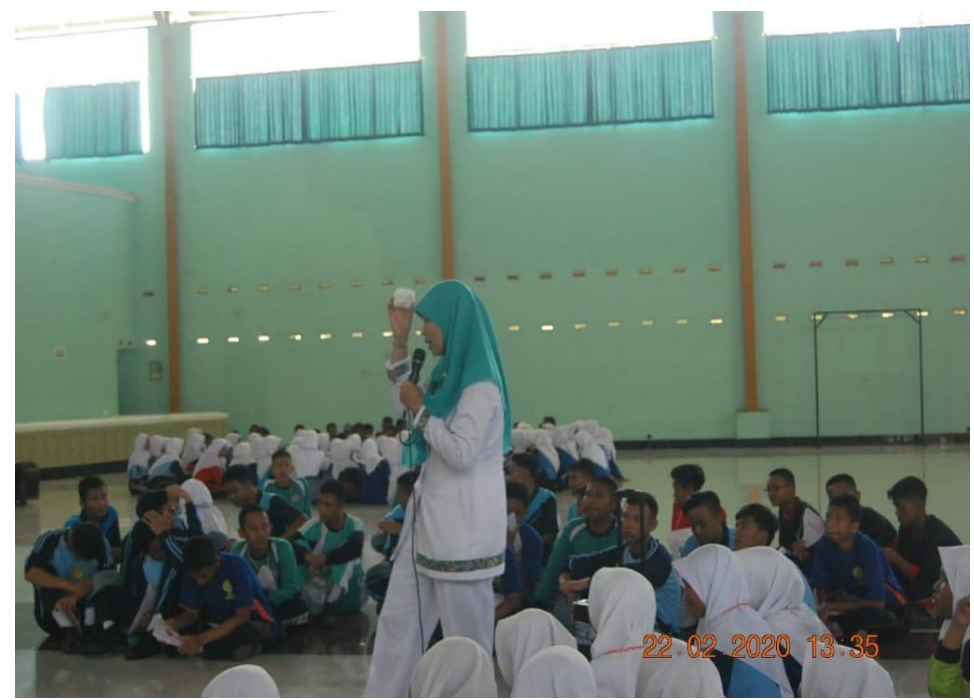

Gambar 3. Menjelaskan alat -alat yang diperlukan untuk penganan luka dan perdarahan

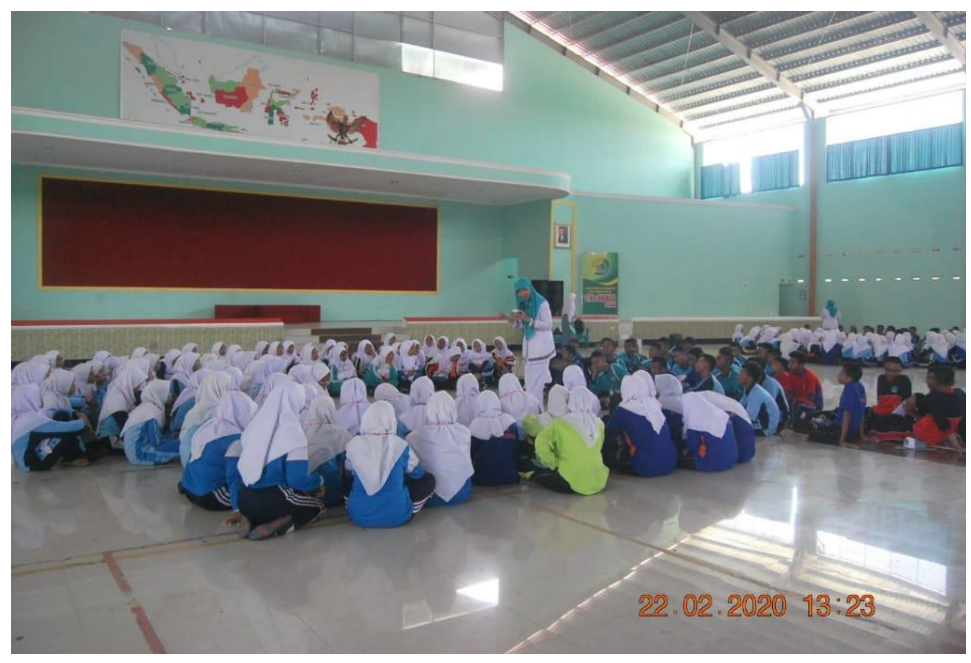

Gambar 4. Menjelaskan dan mempraktekan memposisikan perdarahan

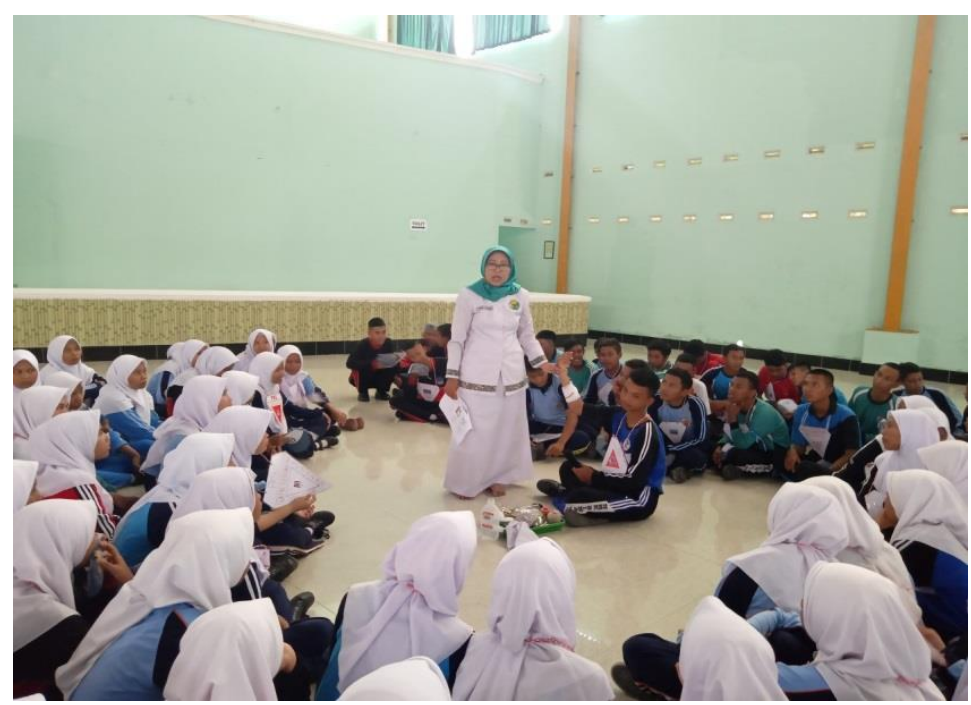

Gambar 5. Korban luka dan perdarahan sedang praktek posisi 


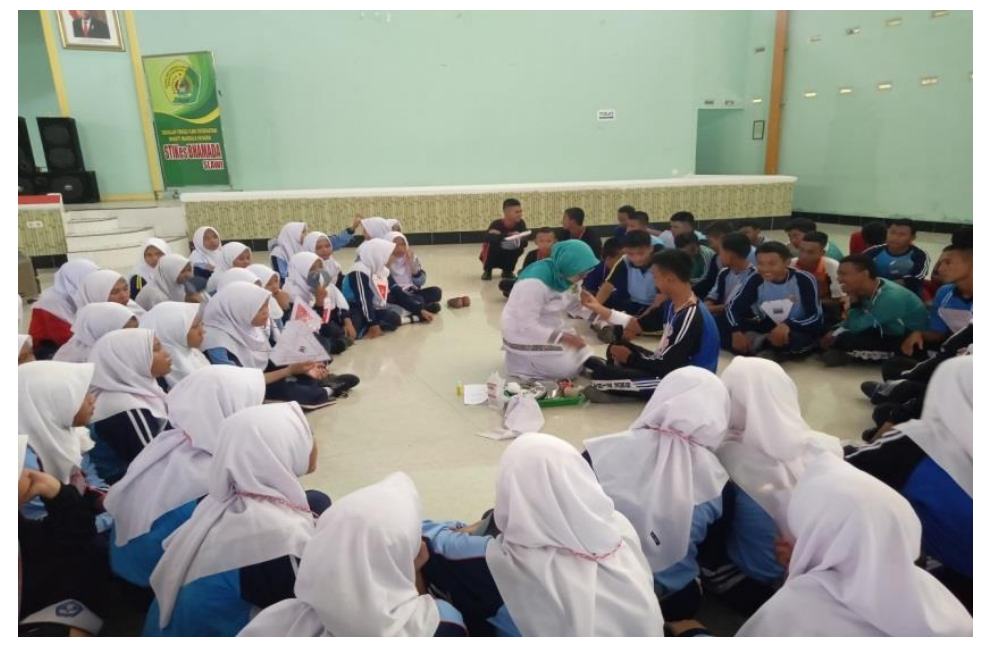

Gambar 6. Mendemostrasikan penanganan pada luka dan perdarahan dan salah satu peserta meredemostrasi

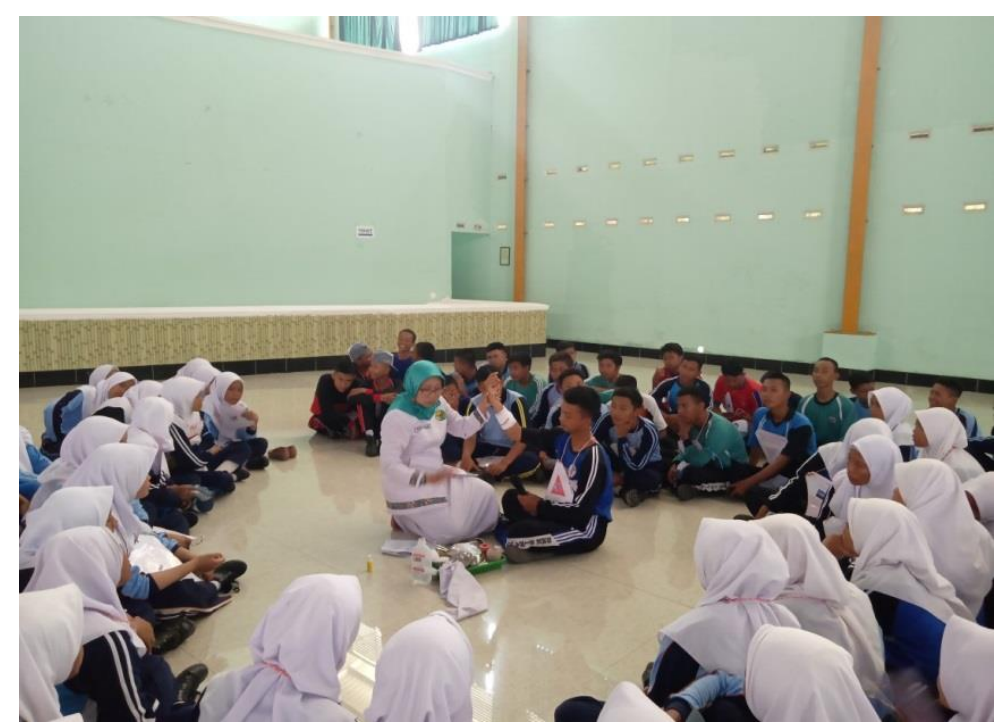

Gambar 7. Salah satu contoh korban yang sudah dilakukan penanganan

Luka adalah hilang atau rusaknya sebagian jaringan tubuh dan sangat beriko terjadi infeksi, secara fisiologi tubuh mempunyai pertahanan yang sangat diperlukan barier alami yang melindungi tubuh susunan jaringan dan sekresi bakterisida yang utama adalah kulit yang utuh susunan anatomi kulit terdiri dari epidermis, dermis, hipodermis (pembuluh darah didalamnya), faktor pencetus adanya trauma seperti luka dan perdarahan akan dapat menggangu sistem pertahanan tubuh manusia (Kneale, Davis, 2011) luka dan perdarahan dapat disebabkan berbagai sebab antara lain : trauma tumpul, perubahan suhu, zat kimia, trauma benda tajam, atau gigitan hewan, jenis luka terdiri dari luka sayat (vulnus scissum) luka tusuk (vulnus punctum), luka robek (vulnus laseratum, luka gesek (eskoriasi) serta adanya luka bakar (Hardisman, 2013). 
Luka bakar adalah cedera yang cukup sering terjadi dimasyarakat umum yang dapat disebabkan oleh zat kimia, thermal, sengatan listrik dan penyebab lainnya. Komplikasi yang sering terjadi pada luka adalah perdarahan hal ini disebabkan oleh karena robeknya pembuluh darah yang ada didalam jaringan, perdarahan yang banyak dan tidak segera diatasi akan dapat menyebabkan seseorang akan kehabisan darah mengakibatkan kematian akibat syok hipovolemia (Hardisman, 2013).

Penangganan pertama apabila seseorang mengalami perdarahan tindakan yang dilakukan adalah menghentikan perdarahan dengan menekan langsung pada lokasi perdarahan bisa menghentikan sumber perdarahan dengan menggunakan kain yang digulung atau alat/benda lainya dengan cukup kuat, pada saat melakukan pertolongan baik luka dan perdarahan tidak mengunakan apapun untuk menghentikan perdarahan seperti mengoleskan oli, minyak rem dan sejenisnya, posisi yang wajib diperhatikan adalah posisikan daerah yang mengalami perdarahan lebih tinggi daripada jantung dan pertahankan balut tekan sampai bantuan datang (Kemenkes RI, 2019). Prinsip pertolongan harus tetap mempertimbangkan safety (keselamatan) meliputi penolong dan korban sehingga penolong harus benar benar memahami kondisi lingkungan tersebut

Dengan adanya kegiatan focus group discussion maka diharapkan anggota Patroli keamanan sekolah mampu memahami dan melakukan pertolongan pertama sehingga dapat meminimalisir komplikasi lebih lanjut yang diakibatkan luka dan perdarahan, sesuai dengan penelitian Mulyadi dan Maikel Killing (2018) dengan judul pengaruh pendidikan kesehatan perawatan luka akibat kecelakaan terhadap tingkat pengetahuan dan sikap Pertolongan pertama pada siswa kelas X diSMK 6 Manado hasilnya terdapat peningkatan yang signifikan dengan sebelum diberikan pendidikan kesehatan 6,62 menjadi 60,62.

Evaluasi yang dapat disampaikan adalah bahwa terjadi peningkatan pengetahuan dibuktikan siswa mampu menjawab pertanyaan, dan evaluasi untuk kegiatan kedepanny adalah menambah durasi waktu sehingga siswa dapat melakukan demostrasi satu persatu untuk cara penanganan luka dan perdarahan. 


\section{KESIMPULAN DAN SARAN}

Kegiatan focus group discussion dapat meningkatkan pengetahuan dan pemahaman peserta dalam penanganan kecelakaan dilingkungan sekolah khususnya luka dan perdarahan dengan adanya pemahaman yang baik apabila terjadi kecelakaan luka dan perdarahan maka dapat melakukan penanganan dini sehingga komplikasi lebih lanjut tidak terjadi,hendaknya kegiatan kedepannya tidak hanya memahami secara kognitif tetapi mampu mempraktekan secara maksimal satu perstu bagaimana penanganan luka dan perdarahan dapat terjadi dengan memperpanjang durasi waktu pelaksanaan.

\section{UCAPAN TERIMAKASIH}

Kepada bapak DR Risnanto, M.Kes Selaku Ketua Stikes Bhamada Salwi, Bapak AKBP M. Iqbal Simatupang, SIK selaku Kapolres Tegal, Bapak AKP Faris Budiman, SH, SIK selaku KASAT LANTAS Polres Tegal beserta jajarannya, Ibu Natiqotul Fathkiyah, SST, M.Kes Selaku Ka UP2M Stikes Bhamada Slawi dan Seluruh peserta FGD PKS SATLANTAS POLRES TEGAL

\section{DAFTAR PUSTAKA}

Hardisman (2014), Gawat darurat medis praktis, Yogyakarta Penerbit Gosyen Publishing

Kemenkes RI.(2019). Buku Saku Pertolongan Pertama Pada Kecelakaan dijalan jadilah penolong kecelakan dijalan semua orang bisa jadi penolong, Jakarta Penerbit Kemenkes RI

Kneale D Julia dan Davis Peter.(2011), Keperawatan ortopedik dan Trauma, Ed 2, Jakarta Penerbit EGC

Medical service and training 119, EMS 119 3.( 2018). Buku panduan BTCLS Ed 3, Jakarta

Mulyadi, Mikail Killing. (2018). Pengaruh Pendidikan Kesehatan Perawatan Luka akibat kecelakaan teradap tingkat pengetahuan dan sikap pertolongan pertama pada siswa kelas X di SMK 6 Manado. E Journal keperawatan volume 6 Nomor 1 hal 5

Soedirman.( 2013). Tindakan tanggap Darurat ed 1, Danadyaksa Published Yogyakarta

Patroli Keamanan Sekolah id.Wikipedia.org/wiki/patroli_keamanan_sekolah 